Short communication

\title{
Synthesis of platinum(II) and palladium(II) complexes with 9,9-dihexyl-4,5-diazafluorene and their in vivo antitumour activity against Hep3B xenografted mice
}

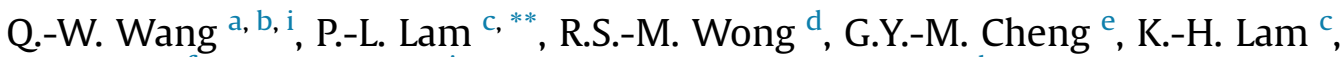

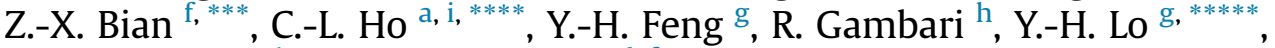 \\ W.-Y. Wong ${ }^{\text {a, c, i, } * * * * * *}$, C.-H. Chui ${ }^{\text {c, d, f, * }}$ \\ ${ }^{a}$ Institute of Molecular Functional Materials, Department of Chemistry and Partner State Key Laboratory of Environmental and Biological Analysis, Hong \\ Kong Baptist University, Hong Kong, PR China \\ b Chengdu Institute of Organic Chemistry, Chinese Academy of Sciences, Chengdu, 610041, PR China \\ ' State Key Laboratory of Chirosciences, Department of Applied Biology and Chemical Technology, The Hong Kong Polytechnic University, Hong Kong, PR \\ China \\ ${ }^{\mathrm{d}}$ Department of Medicine and Therapeutics, The Chinese University of Hong Kong, Hong Kong, PR China \\ e Faculty of Health Sciences, University of Macau, Macau, PR China \\ ${ }^{\mathrm{f}}$ Clinical Division, School of Chinese Medicine, Hong Kong Baptist University, Hong Kong, PR China \\ ${ }^{\mathrm{g}}$ Department of Applied Physics and Chemistry, University of Taipei, Taipei, 100, Taiwan \\ ${ }^{\mathrm{h}}$ Centre of Biotechnology, Department of Life Sciences and Biotechnology, University of Ferrara, Ferrara, Italy \\ ${ }^{\mathrm{i}}$ HKBU Institute of Research and Continuing Education, Shenzhen Virtual University Park, Shenzhen, 518057, PR China
}

\section{A R T I C L E I N F O}

\section{Article history:}

Received 7 May 2016

Received in revised form 16 August 2016

Accepted 17 August 2016

Available online 18 August 2016

\section{Keywords:}

Platinum-diazafluorene complex

Palladium-diazafluorene complex Antitumour

In vivo

\begin{abstract}
A B S T R A C T
Two complexes dichloro(9,9-dihexyl-4,5-diazafluorene)platinum(II) (Pt-DHF) and dichloro(9,9-dihexyl4,5-diazafluorene)palladium(II) (Pd-DHF) were synthesized and their in vivo antitumour activity was investigated using an athymic nude mice model xenografted with human Hep3B carcinoma cells. PtDHF- and Pd-DHF-treated groups showed significant tumour growth inhibition (with about 9-fold and 3-fold tumour growth retardation) when compared with the vehicle control group. The liver toxicology effects on the animals of the two compounds were investigated. Pt-DHF and Pd-DHF-treated groups had a lower alanine transaminase and aspartate transaminase values than those of the vehicle treated group as the animals from the vehicle control group had very heavy hepatoma burden. We assume that both complexes could be further investigated as effective antitumour agents and it is worthwhile to study their underlying working mechanism.
\end{abstract}

๑) 2016 Elsevier Masson SAS. All rights reserved.

\footnotetext{
* Corresponding author. Clinical Division, School of Chinese Medicine, Hong Kong Baptist University, Hong Kong, PR China.

** Corresponding author.

*** Corresponding author.

***** Corresponding author. Institute of Molecular Functional Materials, Department of Chemistry and Partner State Key Laboratory of Environmental and Biological Analysis, Hong Kong Baptist University, Hong Kong, PR China.

****** Corresponding author.

****** Corresponding author. Institute of Molecular Functional Materials, Department of Chemistry and Partner State Key Laboratory of Environmental and Biological Analysis, Hong Kong Baptist University, Hong Kong, PR China.

E-mail addresses: tcstacey@polyu.edu.hk (P.-L. Lam), bzxiang@hkbu.edu.hk (Z.-X. Bian), clamho@hkbu.edu.hk (C.-L. Ho), yhlo@utaipei.edu.tw (Y.-H. Lo), rwywong@hkbu.edu.hk (W.-Y. Wong), chchui@hkbu.edu.hk (C.-H. Chui).
}

\section{Introduction}

Metal complexes are important in the development of antitumour drugs because of the interaction between metal complexes with biomolecules in human body and the high stability of their final products under various conditions. Metal complexes have been employed in antitumour therapy since the discovery of the cytotoxicity of cisplatin (cis- $\mathrm{Pt}\left(\mathrm{NH}_{3}\right)_{2} \mathrm{Cl}_{2}$ ) by Rosenberg and coworkers in the late 1960s [1,2]. Cisplatin was the first identified member of the platinum-based chemotherapeutic drugs. It has been applied clinically for more than three decades in oncology $[2,3]$. The introduction of cisplatin to the antitumour therapy has initiated the design and synthesis of metal complexes including platinum and palladium to improve the therapeutic activity of the 
antitumour drugs.

$\mathrm{Pt}(\mathrm{II})$ ion has a strong binding ability to sulfur. After taking the Pt(II)-based drug in the human body, there is a high potential for binding with sulfur-donor biomolecules, which can be found in peptides, proteins and enzymes. The interaction of $\mathrm{Pt}(\mathrm{II})$ complexes with S-containing biomolecules can lead to strong cytotoxicity [4,5]. The anti-tumour activity of Pt(II)-based drugs can be due to the interaction between the metal complex and genomic DNA $[4,6]$. Owing to the structural similarities and significant overlap of the coordination chemistry for palladium and platinum, these two metals are closely related [7]. Palladium related complexes have also been investigated intensively in the field of medicinal chemistry $[8,9]$.

Utku et al. reported the in vitro anticancer activity of the synthesized benzimidazole-platinum(II) complexes on the human HeLa (ER-), MCF-7 (ER+) and MDA-MB 231 (ER-) cell lines. Pt(II) complex bearing oxalate leaving ligand possessed the most active anticancer activity, with about two or five-fold greater than those of the other benzimidazole-platinum complexes tested [10]. Kovala-Demertzi and co-workers studied the anticancer property of the palladium(II) complexes synthesized by the reaction of $\mathrm{Pd}(\mathrm{II})$ salt with 2-formylpyridine-4- $\mathrm{N}$-ethyl-thiosemicarbazone, HFo4NEt. The complex $\left[\mathrm{Pd}\left(\mathrm{H}_{2} \mathrm{Fo} 4 \mathrm{NEt}\right)(\mathrm{Fo} 4 \mathrm{NEt}) \mathrm{Cl}_{2}\right]$ exhibited a better anticancer activity, with the $\mathrm{IC}_{50}$ values against MCF-7 and $\mathrm{T}-24$ cancer cell lines being 8.42 and $5.88 \mu \mathrm{M}$, respectively, when compared with the complexes [Pd(Fo4Nethyl)Cl] $\left(\mathrm{IC}_{50}=104.1\right.$ and $72.5 \mu \mathrm{M})$ and $\left[\mathrm{Pd}(\text { Fo4Nethyl })_{2}\right]\left(\mathrm{IC}_{50}=14.52\right.$ and $\left.7.59 \mu \mathrm{M}\right)$ [11]. Motswainyana and co-workers examined the anticancer property of the synthesized palladium(II) and platinum(II) complexes: dichloro[(2-diphenylphosphino-benzylidene)-2-methylphenylenamine]palladium(II), dichloro[2-diphenylphosphino-benzylidene)-2,6-dimethylphenylen-amine]palladium(II), dichloro-[(2diphenylphosphino-benzylidene)-2-methylphenylen-amine]platinum(II) and dichloro-[2-diphenylphosphino-benzylidene)-2,6dimethylphenylen-amine]platinum(II). Both palladium(II) complexes possessed a stronger cytotoxicity towards MCF-7 and HT-29 cancer cell lines (mean $\mathrm{IC}_{50}=28.5-48 \mu \mathrm{M}$ ) when compared with the platinum(II) complexes (mean $\mathrm{IC}_{50}=50-87 \mu \mathrm{M}$ ) [12]. This team further reported that the synthesized bis(imino-quinolyl) platinum(II) complex displayed a slightly stronger anticancer activity (mean $\mathrm{IC}_{50}=55$ and $41 \mu \mathrm{M}$ against MCF-7 and HT-29 cancer cells, respectively) when compared with the bis(imino-quinolyl) palladium(II) complex (mean $\mathrm{IC}_{50}=60$ and $46 \mu \mathrm{M}$ ) [13]. Oliveira et al. investigated the anticancer activity of complexes containing palladium(II) and platinum(II): $\left[\mathrm{Pd}\left(\mathrm{NH}_{3}\right)_{4}\right][\mathrm{Pd}($ opba $)]$ and $\left[\mathrm{Pt}\left(\mathrm{H}_{2} \mathrm{opba}\right)\right] \cdot \mathrm{H}_{2} \mathrm{O}$, where opba $=1,2$-phenylenebis(oxamate) against the chronic myelogenous leukemia cell line. The palladium(II) complex $\left[\mathrm{Pd}\left(\mathrm{NH}_{3}\right)_{4}\right][\mathrm{Pd}($ opba $)]$ showed a better growth inhibition against leukemia cells (mean $\mathrm{IC}_{50}=19.9 \mu \mathrm{M}$ ) than the platinum(II) complex $\left[\mathrm{Pt}\left(\mathrm{H}_{2} \mathrm{Opba}\right)\right] \cdot \mathrm{H}_{2} \mathrm{O}\left(\right.$ mean $\left.\mathrm{IC}_{50}=27.35 \mu \mathrm{M}\right)$ [14].
Barbara et al. reported the in vitro and in vivo biological properties of two bile acid-conjugated platinum(II) complexes: $\left(\mathrm{NH}_{3}\right)_{2} \mathrm{Pt}$ (triacid) and $\left(\mathrm{PPh}_{3}\right)_{2} \mathrm{Pt}(\text { dehydrocholate })_{2}$. $\left(\mathrm{NH}_{3}\right)_{2} \mathrm{Pt}$ (triacid) showed a stronger growth inhibition on rat hepatoma cells (mean $\left.\mathrm{IC}_{50}=0.7 \mu \mathrm{M}\right)$ after $48 \mathrm{~h}$ when compared with $\left(\mathrm{PPh}_{3}\right)_{2} \mathrm{Pt}$ (dehydrocholate $)_{2}$ (mean $\mathrm{IC}_{50}=3.8 \mu \mathrm{M}$ ). In a syngeneic and orthotopic rat hepatoma model, the $\left(\mathrm{NH}_{3}\right)_{2} \mathrm{Pt}$ (triacid)-treated group displayed more than 6-fold tumour weight reduction at the dose of $80 \mathrm{mg} / \mathrm{kg}$ as compared to the control group and the $\left(\mathrm{PPh}_{3}\right)_{2} \mathrm{Pt}$ (dehydrocholate) 2 -treated group [15].

It appears that most of these studies have focused on in vitro anticancer analysis while in vivo antitumour studies including tumour size reduction evaluation have been infrequently reported. In our present study, two platinum(II) and palladium(II) complexes with 9,9-dihexyl-4,5-diazafluorene (DHF) derivatives were synthesized and their in vivo antitumour activities were investigated using an athymic nude mice model xenografted with human Hep3B carcinoma cells.

\section{Results and discussion}

\subsection{Chemistry}

The chemical structures and the synthetic protocols of the novel diazafluorene-based organic compounds are shown in Scheme 1. 9,9-Dihexyl-4,5-diazafluorene (DHF) was prepared using the method reported in the previous paper [16]. Platinum(II)-9,9dihexyl-4,5-diazafluorene (Pt-DHF) complex was obtained from DHF by treatment with $\mathrm{K}_{2} \mathrm{PtCl}_{4}$ in water solution in the presence of a catalytic amount of conc. $\mathrm{HCl}$ in a high yield of $80 \%$ [17], while palladium-9,9-dihexyl-4,5-diazafluorene (Pd-DHF) congener was successfully synthesized using $\mathrm{Na}_{2} \mathrm{PdCl}_{4}$ in $\mathrm{CH}_{2} \mathrm{Cl}_{2}$ solution in $86 \%$ yield [18]. These air-stable compounds were isolated in high purity as golden or brown solids by column chromatography on silica gel eluting with $\mathrm{CH}_{2} \mathrm{Cl}_{2}$. These compounds were fully characterized by NMR (both ${ }^{1} \mathrm{H}$ and ${ }^{13} \mathrm{C}$ ) spectroscopy (see Supporting Information) and fast atom bombardment mass spectrometry (FAB-MS). Both of them can afford good single crystals for X-ray diffraction analysis from their solid samples (Figs. 1 and 2). Based on our prior results with 4,5-diazafluoren-9-one as the coordinated ligands which showed very poor solubility in common solvents [18], we have purposely substituted the oxo group with long alkyl chains at the 9position of fluorene in the present study to tune the solubility and hydrophobility of the metal complexes. The ligand DHF has been shown to possess a certain level of antitumour activity in athymic nude mice xenografted with human Hep3B carcinoma cells [16]. Since metal ions are promising candidates that have been successfully used for anticancer therapy [19], the potential antitumour potency was further investigated after the incorporation of metal ions (Pt and Pd) into the DHF (see Table 1).

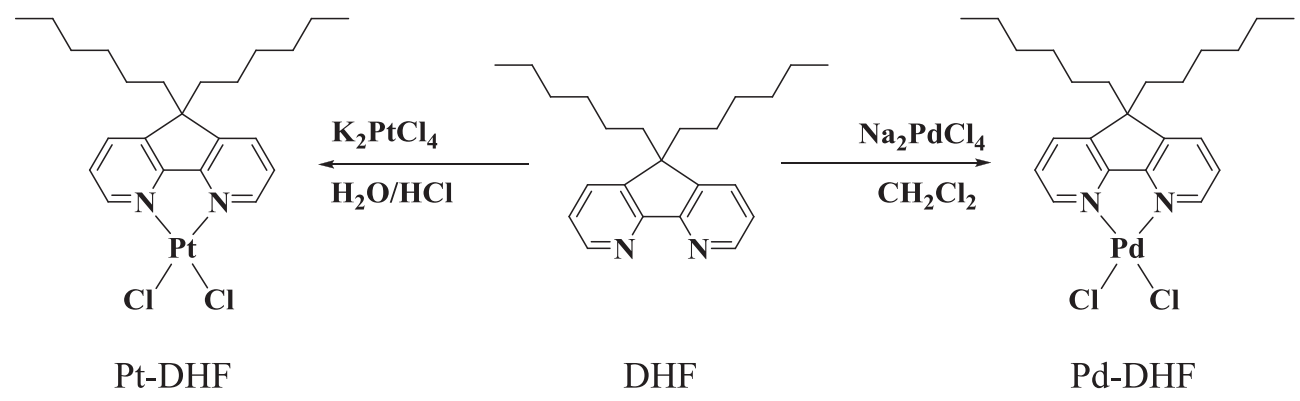

Scheme 1. Synthetic profiles of Pt-DHF and Pd-DHF. 


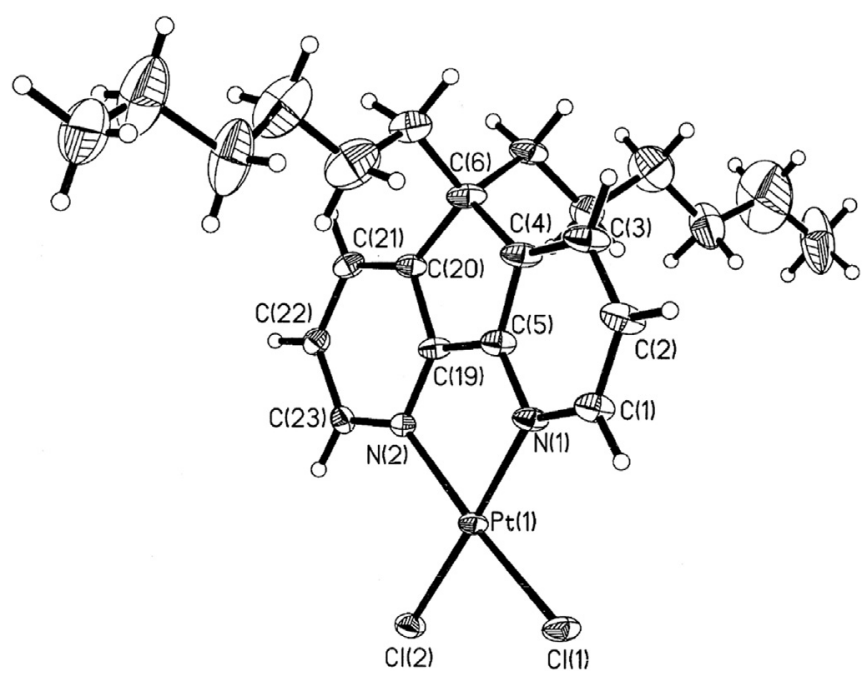

Fig. 1. Solid-state structure of Pt-DHF. Selected bond distances $(\AA)$ and angles $\left(^{\circ}\right)$ : $\mathrm{Pt}(1)-\mathrm{Cl}(1)$ 2.271(1); $\mathrm{Pt}(1)-\mathrm{Cl}(2)$ 2.281(1); $\mathrm{Pt}(1)-\mathrm{N}(1)$ 2.047(4); $\mathrm{Pt}(1)-\mathrm{N}(2)$ 2.073(3); $\mathrm{N}(1)-\mathrm{Pt}(1)-\mathrm{N}(2)$ 83.8(1); Cl(1)-Pt(1)-Cl(2) 92.89(4).

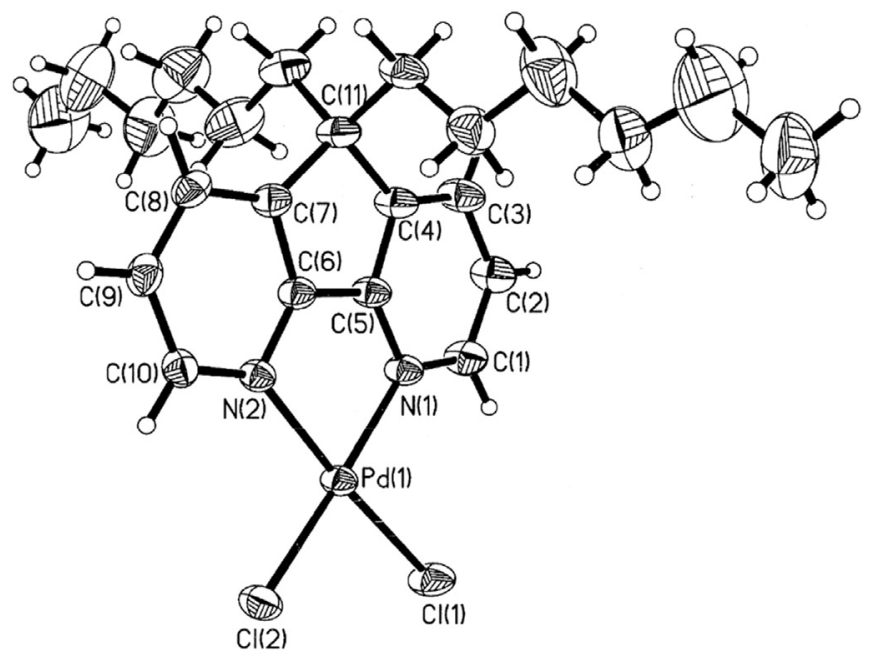

Fig. 2. Solid-state structure of Pd-DHF Selected bond distances $(\AA)$ and angles $\left(^{\circ}\right)$ : $\mathrm{Pd}(1)-\mathrm{Cl}(1)$ 2.2611(7); $\mathrm{Pd}(1)-\mathrm{Cl}(2)$ 2.2707(7); $\mathrm{Pd}(1)-\mathrm{N}(1)$ 2.069(2); $\mathrm{Pd}(1)-\mathrm{N}(2)$ 2.093(2); $\mathrm{N}(1)-\mathrm{Pd}(1)-\mathrm{N}(2)$ 84.31(8); $\mathrm{Cl}(1)-\mathrm{Pd}(1)-\mathrm{Cl}(2)$ 93.18(3).

\subsection{Preliminary animal experiments}

Athymic nude mice xenografted with human Hep3B carcinoma cells were used as a model for this study. Mice with Hep3B cancer cells xenografted of average tumour volume from $200 \mathrm{~mm}^{3}$ received intraperitioneal injection daily of either of buffer vehicle (saline for injection) or equal volume of Pt-DHF and Pd-DHF at $10 \mathrm{mg} \mathrm{kg}^{-1}$ for 9 consecutive days, respectively. The treatment stopping time (day 10) for tumour appearances of mice are shown in Fig. 3. As shown in Figs. 3 and 4, both Pt-DHF- and Pd-DHFtreated groups showed significant tumour growth inhibition (with about 9-fold and 3-fold tumour growth retardation, respectively) when compared with the vehicle control group at the end of the study. Both Pt-DHF and Pd-DHF revealed a stronger tumour growth inhibition than the ligand DHF itself (which was only about 2 -fold tumour growth retardation [16] at the same dose of $10 \mathrm{mg} \mathrm{kg}^{-1}$ body weight). These results suggest the importance for the incorporation of Pt and Pd into the DHF as antitumour agents. Noticeably, extensively necrotic feature could be detected from the Pt-DHF-treated mice (Fig. 5B). For both the vehicle control group
Table 1

Crystallographic data.

\begin{tabular}{|c|c|c|}
\hline Compound & Pt-DHF & Pd-DHF \\
\hline $\mathrm{CCDC}$ & 1452122 & 1452123 \\
\hline Formula & $\mathrm{C}_{23} \mathrm{H}_{32} \mathrm{Cl}_{2} \mathrm{~N}_{2} \mathrm{Pt}$ & $\mathrm{C}_{23} \mathrm{H}_{32} \mathrm{Cl}_{2} \mathrm{~N}_{2} \mathrm{Pd}$ \\
\hline Formula weight & 602.5 & 513.81 \\
\hline Crystal system & Hexagonal & Hexagonal \\
\hline space group & $P 3_{2} 2_{1}$ & $P 3_{2} 2_{1}$ \\
\hline$a / \AA ̊$ & $12.3554(3)$ & $12.452(1)$ \\
\hline$b / \AA$ & $12.3554(3)$ & $12.452(1)$ \\
\hline$c / \AA$ & $26.5988(1)$ & $26.767(4)$ \\
\hline$\alpha /^{\circ}$ & 90 & 90 \\
\hline$\beta 1^{\circ}$ & 90 & 90 \\
\hline$\left.\gamma\right|^{\circ}$ & 120 & 120 \\
\hline $\mathrm{V} / \AA^{3}$ & $3516.5(2)$ & $3594.2(7)$ \\
\hline$Z^{\prime}$ & 6 & 6 \\
\hline Temperature/K & $173(2)$ & $293(2)$ \\
\hline$\mu\left(\right.$ Mo $\left.K_{\alpha}\right) / \mathrm{mm}^{-1}$ & 6.224 & 1.008 \\
\hline$D$ (calcd) $/ \mathrm{g} \mathrm{cm}^{-3}$ & 1.707 & 1.424 \\
\hline Collected refl. & 21334 & 21967 \\
\hline Unique refl. & 5756 & 5916 \\
\hline$R_{\text {int }}$ & 0.036 & 0.0203 \\
\hline$R_{1}^{\mathrm{a}}[I>2 \sigma(I)]$ & 0.0262 & 0.0241 \\
\hline$w R_{2}^{\mathrm{b}}[I>2 \sigma(I)]$ & 0.0526 & 0.0611 \\
\hline$R_{1}$ [all data] & 0.0321 & 0.0281 \\
\hline$w R_{2}$ [all data] & 0.0543 & 0.0637 \\
\hline GOF & 1.07 & 1.039 \\
\hline$\Delta \rho / \mathrm{e} \AA^{-3}$ & $0.725,-0.484$ & $0.278,-0.291$ \\
\hline
\end{tabular}

${ }^{\mathrm{a}} R_{1}=\Sigma\left(\left|F_{o}\right|-\left|F_{c}\right|\right) / \Sigma\left|F_{o}\right|$.

b $w R_{2}=\left\{\Sigma\left[w\left(F_{o}^{2}-F_{c}^{2}\right)^{2}\right] / \Sigma\left[w\left(F_{o}^{2}\right)^{2}\right]\right\}^{1 / 2}$.

(Fig. 5A) and the Pd-DHF-treated group (Fig. 5C), tumour section displayed high cellular integrity.

In order to demonstrate whether the Pt-DHF and Pd-DHF at $10 \mathrm{mg} \mathrm{kg}^{-1}$ body weight has any possible toxicology effects on the animals under the current therapeutic protocol, hematoxylin and eosin ( $\mathrm{H}$ and $\mathrm{E}$ ) staining of liver sections (Fig. 5A-C) and plasma liver functional enzyme analysis including ALT and AST (Fig. 6) were investigated. Neither necrotic nor damaged tissue could be observed from the histological staining study of liver sections from sacrificed mice in all treated groups (Fig. 5D-F). Fig. 6 shows that both Pt-DHF and Pd-DHF-treated groups had a lower ALT and AST values than those of the vehicle treated group since the animals from the vehicle control group had very heavy hepatoma burden. Conclusively, no observable hepatic adverse effect could be identified when Pt-DHF or Pd-DHF at a concentration of $10 \mathrm{mg} \mathrm{kg}^{-1}$ body weight per day was administrated intraperitoneally in athymic nude mice.

\section{Conclusions}

We have demonstrated that the Pt-DHF and Pd-DHF complexes showed a much stronger in vivo antitumour activity than the DHF compound. The complexes-treated groups had a lower ALT and AST values than those of the vehicle treated group, suggesting that they exerted low liver toxicity under the therapeutic dosage $\left(10 \mathrm{mg} \mathrm{kg}{ }^{-1}\right)$. Our work here implies the importance of metal containing drugs for further antitumour regimen development. We assume that it is worthwhile to further study their underlying working mechanism and compare with those conventional metal containing antitumour regimens.

\section{Experimental section}

\subsection{Chemistry}

\subsubsection{General methods}

All of the manipulations were performed under a dry nitrogen 
Mice 1
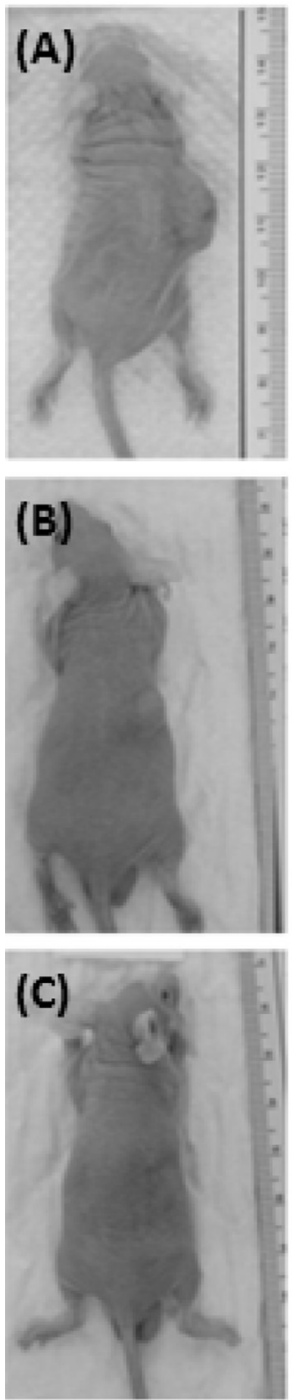

Mice 2
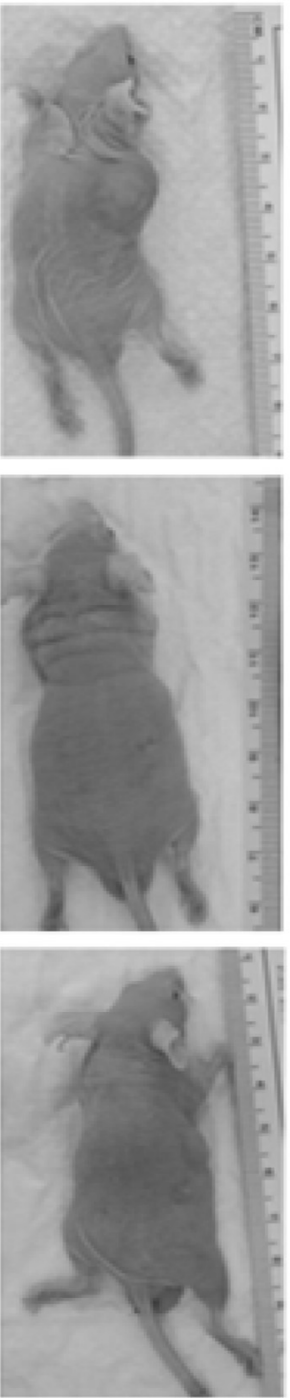

Mice 3
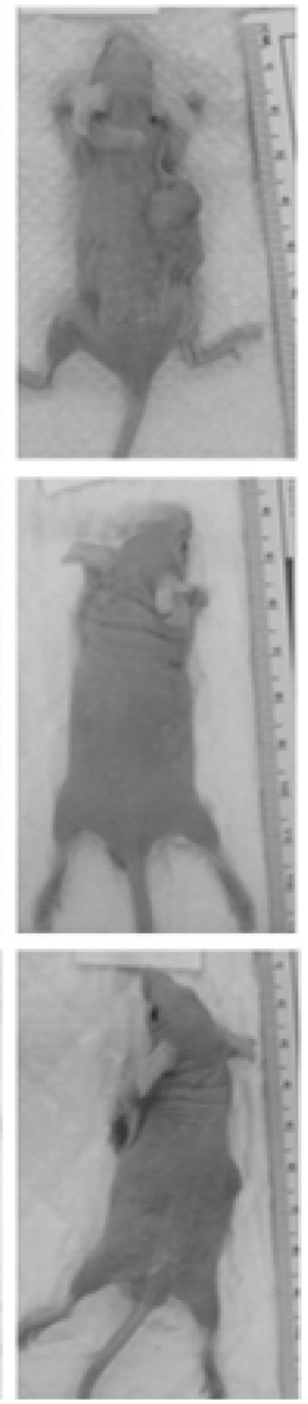

Mice 4
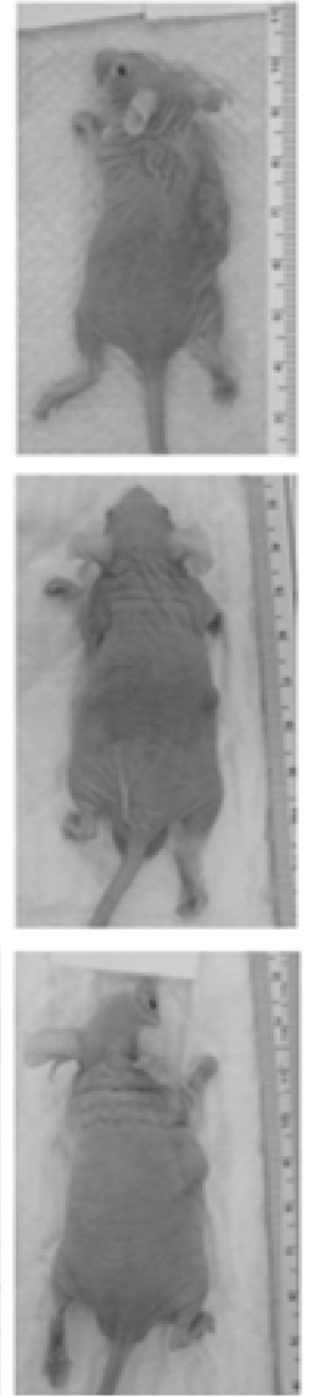

Mice 5
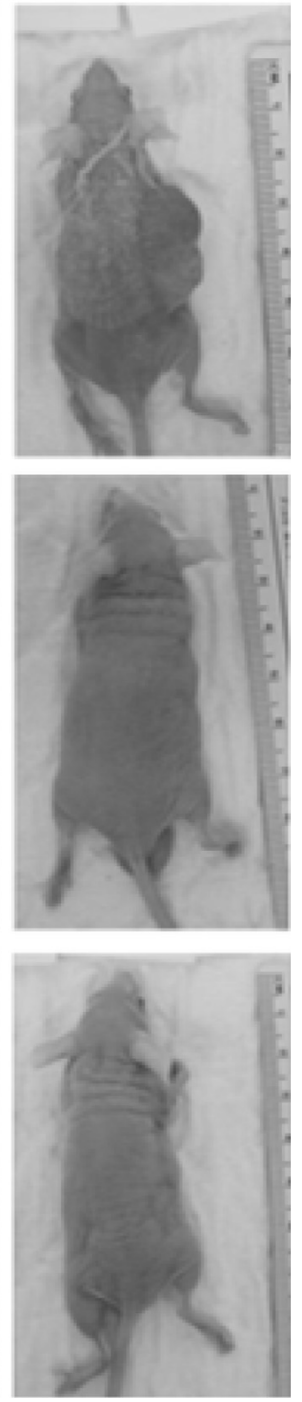

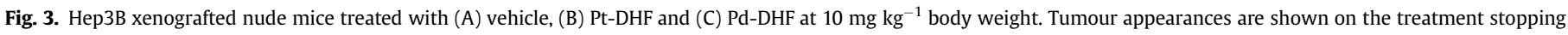
time (day 10).

atmosphere by using Schlenk techniques. Solvents were dried by standard methods and distilled prior to use. All reagents and chemicals, unless otherwise stated, were purchased from commercial sources and used without further purification. Separation and purification of products were achieved by column chromatography on silica gel. The ligand precursor DHF was prepared according to the literature method [16].

\subsubsection{Physical measurements}

NMR spectra were measured in deuterated solvents as the lock and reference on a Bruker AV 400 instrument with ${ }^{1} \mathrm{H}$ and ${ }^{13} \mathrm{C}$ NMR chemical shifts quoted relative to tetramethylsilane standard. The positive-ion fast atom bombardment (FAB) mass spectra were obtained using Finnigan-MAT SSQ710 mass spectrometer. Crystals of our compounds suitable for X-ray diffraction studies were grown by slow evaporation of its solution in dichloromethane/hexane at room temperature and were mounted on a glass fibre. Geometric and intensity data were collected by using graphitemonochromated MoK $\alpha$ radiation $(\lambda=0.71073 \AA)$ on a Bruker Axs SMART 1000 CCD diffractometer. The collected frames were processed with the software SAINT [20] and an absorption correction (SADABS) [21] was applied to the collected reflections. The structures of all compounds were solved by the Direct methods (SHELXTL ${ }^{\mathrm{TM}}$ ) [22] in conjunction with standard difference Fourier techniques and subsequently refined by full matrix least-squares analyses on $F^{2}$. All non-hydrogen atoms were assigned with anisotropic displacement parameters. Hydrogen atoms were generated in their idealized positions and allowed to ride on their respective parent carbon atoms.

\subsubsection{Synthesis of Pt-DHF}

A suspension of $\mathrm{K}_{2}\left[\mathrm{PtCl}_{4}\right]$ (27.2 $\left.\mathrm{mg}, 0.066 \mathrm{mmol}\right)$ in degassed water $(20 \mathrm{~mL})$, DHF $(21.0 \mathrm{mg}, 0.062 \mathrm{mmol})$, and 1 drop $\mathrm{HCl}$ was heated to boiling. Yellow precipitation was obtained, which was filtered off and washed with water. The yellow powder of pure PtDHF was obtained by column chromatography on silica gel eluting with $\mathrm{CH}_{2} \mathrm{Cl}_{2}$ (30.0 mg, $\left.0.049 \mathrm{mmol}, 80 \%\right) .{ }^{1} \mathrm{H} \mathrm{NMR}$ (400 MHz, $\left.\mathrm{CDCl}_{3}\right): \delta=8.87(\mathrm{~m}, 2 \mathrm{H}, \mathrm{Ar}), 8.03(\mathrm{~m}, 2 \mathrm{H}, \mathrm{Ar}), 7.61-7.57(\mathrm{~m}, 2 \mathrm{H}, \mathrm{Ar})$, 2.08-2.04 (m, $\left.4 \mathrm{H}, \mathrm{C}_{6} \mathrm{H}_{13}\right), 1.18-1.12\left(\mathrm{~m}, 12 \mathrm{H}, \mathrm{C}_{6} \mathrm{H}_{13}\right), 0.87-0.80(\mathrm{~m}$, $\left.10 \mathrm{H}, \mathrm{C}_{6} \mathrm{H}_{13}\right) ;{ }^{13} \mathrm{C}$ NMR $\left(100 \mathrm{MHz}, \mathrm{CDCl}_{3}\right): \delta=163.55,146.06,143.18$, 


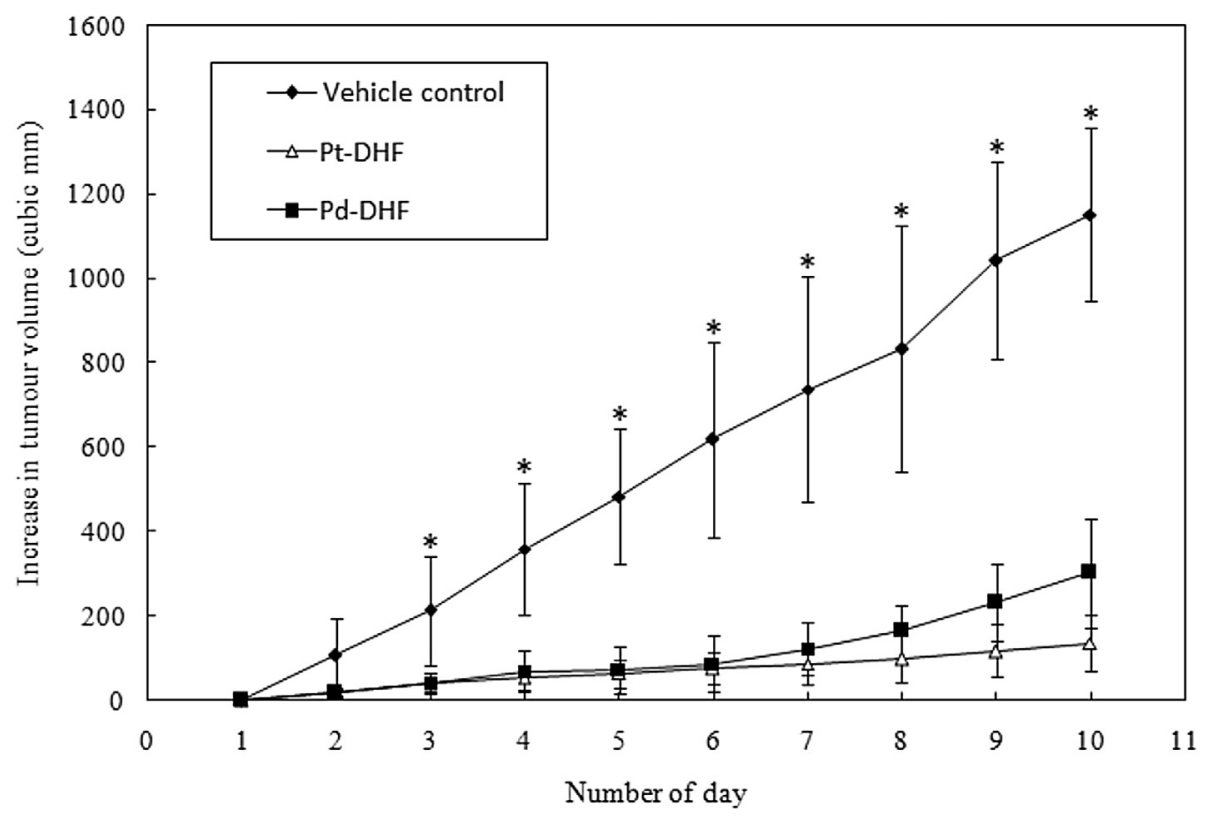

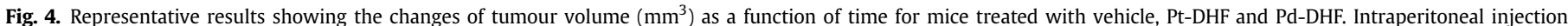

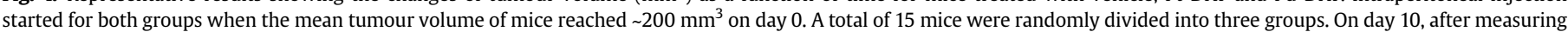

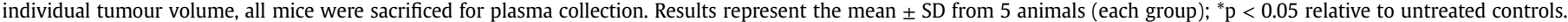
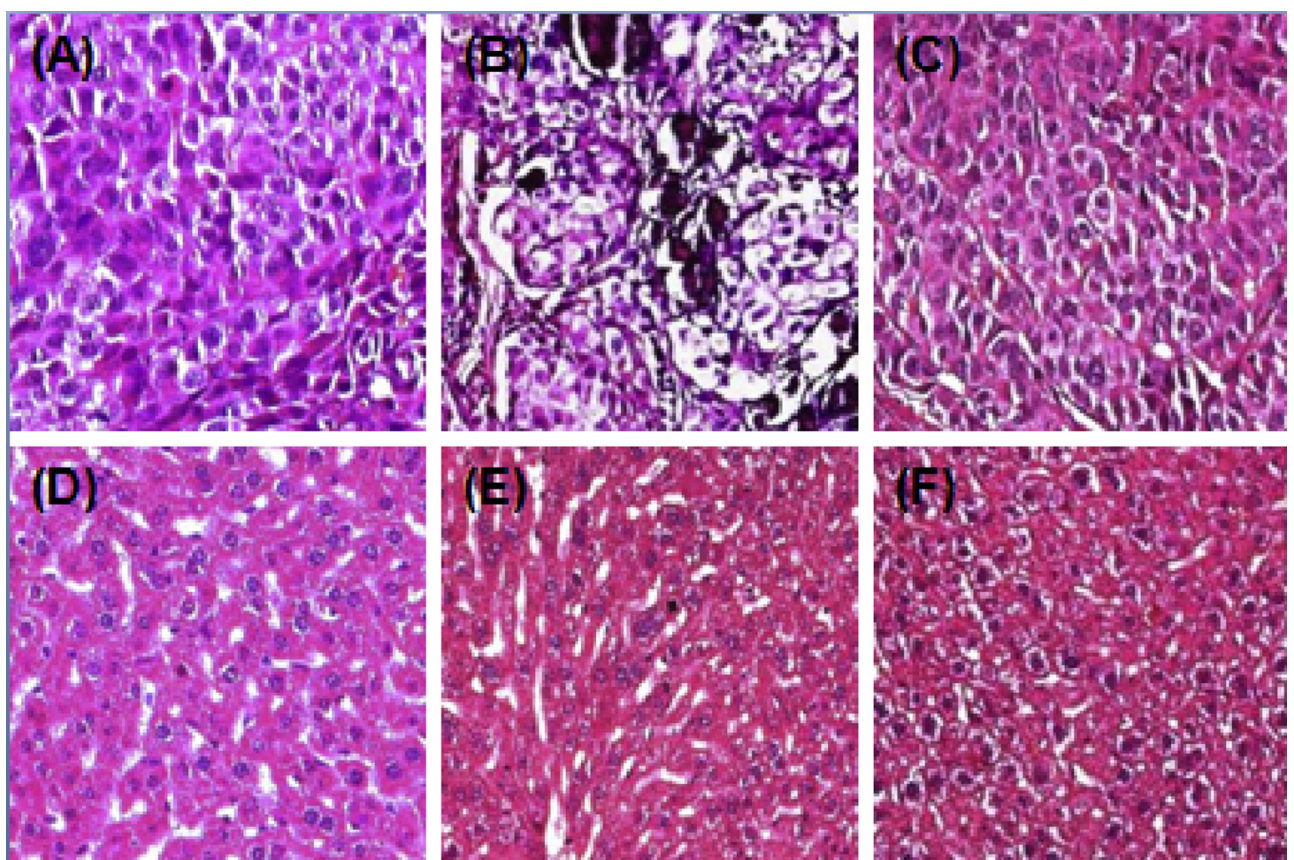

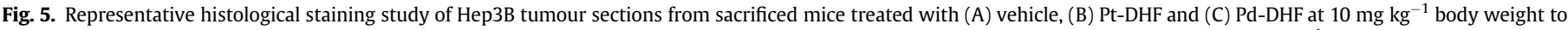

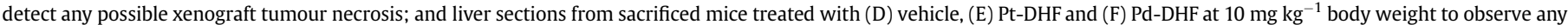
possible liver toxicity.

134.44, 125.82 (Ar), 62.52 (quaternary C), 37.41, 31.20, 29.32, 24.82, 22.43, $13.92\left(\mathrm{C}_{6} \mathrm{H}_{13}\right)$; FAB-MS: $m / z 567.3[\mathrm{M}-\mathrm{Cl}]^{+}$; Anal. calcd for $\mathrm{C}_{23} \mathrm{H}_{32} \mathrm{Cl}_{2} \mathrm{~N}_{2} \mathrm{Pt}$ (\%): C, 45.85; $\mathrm{H}, 5.35 ; \mathrm{N}, 4.65$. Found: $\mathrm{C}, 45.65 ; \mathrm{H}$, $5.40 ; \mathrm{N}, 4.33$.

\subsubsection{Synthesis of Pd-DHF}

A mixture of $\mathrm{PdCl}_{2}(25.0 \mathrm{mg}, 0.14 \mathrm{mmol})$ and $\mathrm{NaCl}(16.5 \mathrm{mg}$, $0.28 \mathrm{mmol}$ ) was stirred in $\mathrm{MeOH}(8 \mathrm{~mL})$. The reaction mixture was warmed on a water bath at $40-50{ }^{\circ} \mathrm{C}$ until all the brown solid was dissolved to give a clear solution. The solution was evaporated to a volume of $1 \mathrm{~mL}$ and was then added to $\mathrm{CH}_{2} \mathrm{Cl}_{2}(3 \mathrm{~mL})$. To this resulting solution mixture consisting of $\mathrm{Na}_{2}\left[\mathrm{PdCl}_{4}\right]$, DHF (47.4 mg, $0.14 \mathrm{mmol}$ ) in $\mathrm{CH}_{2} \mathrm{Cl}_{2}$ (3 mL) was added dropwise to give a brown suspension, which was then centrifuged to remove the liquid phase. The crude product was then purified by column chromatography on silica gel eluting with $\mathrm{CH}_{2} \mathrm{Cl}_{2}$ to give pure Pd-DHF (62.0 $\mathrm{mg}, 0.12 \mathrm{mmol}, 86 \%)$ as a brown solid. ${ }^{1} \mathrm{H}$ NMR $(400 \mathrm{MHz}$, $\left.\mathrm{CDCl}_{3}\right): \delta=8.59(\mathrm{~m}, 2 \mathrm{H}, \mathrm{Ar}), 8.02(\mathrm{~m}, 2 \mathrm{H}, \mathrm{Ar}), 7.59(\mathrm{~m}, 2 \mathrm{H}, \mathrm{Ar})$, 


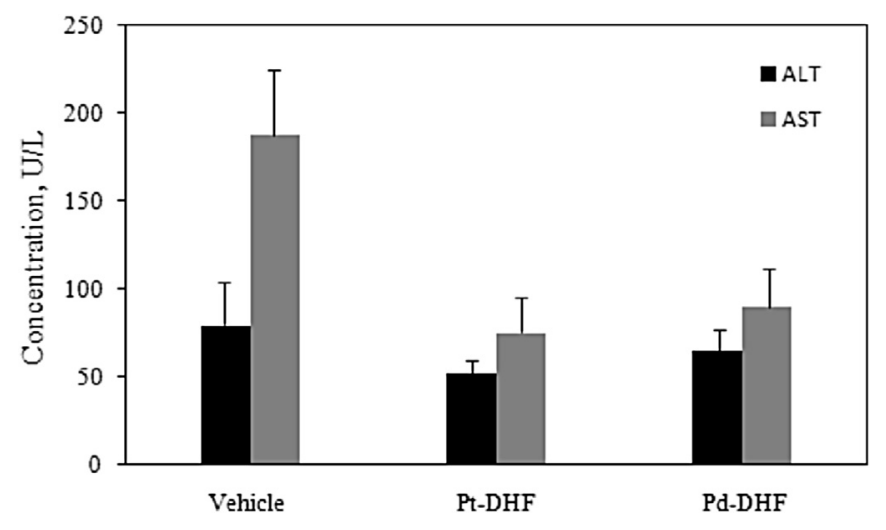

Fig. 6. Plasma liver enzyme assays for vehicle control, Pt-DHF- and Pd-DHF-treated Hep3B xenografted athymic nude mice. $\mathrm{N}=5$ for all vehicle control group, Pt-DHFand Pd-DHF-treated groups (10 $\mathrm{mg} \mathrm{kg}^{-1}$ body weight). Enzymatic levels were determined by the IDEXX laboratories machine using its veterinary biochemistry assay kits and expressed as units per litre. Results represent the mean \pm SD.

2.10-2.05 (m, 4H, $\left.\mathrm{C}_{6} \mathrm{H}_{13}\right), 1.19-1.09\left(\mathrm{~m}, 12 \mathrm{H}, \mathrm{C}_{6} \mathrm{H}_{13}\right), 0.89-0.79(\mathrm{~m}$, $\left.10 \mathrm{H}, \mathrm{C}_{6} \mathrm{H}_{13}\right) ;{ }^{13} \mathrm{C}$ NMR $\left(100 \mathrm{MHz}, \mathrm{CDCl}_{3}\right): \delta=162.18,147.15,143.41$, 135.01, 125.75 ( $\mathrm{Ar}$ ), 61.75 (quaternary C), 37.43, 31.32, 29.32, 24.73, 22.44, $13.95\left(\mathrm{C}_{6} \mathrm{H}_{13}\right)$; FAB-MS: $\mathrm{m} / z$ 479.1 $[\mathrm{M}-\mathrm{Cl}]^{+}$; Anal. calcd for $\mathrm{C}_{23} \mathrm{H}_{32} \mathrm{Cl}_{2} \mathrm{~N}_{2} \mathrm{Pd}$ (\%): C, 53.76; $\mathrm{H}, 6.28 ; \mathrm{N}, 5.45$. Found: C, 53.66; $\mathrm{H}$, 5.99; N, 5.32.

\subsection{Preliminary animal experiments}

\subsubsection{Cell culture}

Human hepatoma Hep3B cells were removed from the sterile cell culture flasks with trypsin and neutralized with fetal bovine serum. After washing with phosphate buffered saline and centrifugation, cells were re-suspended in complete cell culture medium [16,23-25].

\subsubsection{Preliminary in vivo athymic nude mice experiment}

Eight weeks old athymic nude mice, weighing approximately 15-20 g, were purchased from the animal unit of The Chinese University of Hong Kong and maintained in a sterile facility, in accordance with the guidelines from the institute and Department of Health, Hong Kong SAR, on animal care, with the required consistent temperature and relative humidity. Mice were housed under normal regular ambient light condition (a $12 \mathrm{~h}$ light and $12 \mathrm{~h}$ dark cycle) for the whole experimental period. All the procedures were approved by the Animal Research Ethics Committee. Fifteen athymic nude mice were injected subcutaneously with the Hep3B cells. They were housed under a sterile condition. Tumour size was measured by the electronic calliper daily. When tumour size reached about $200 \mathrm{~mm}^{3}$ whereas the tumour volume was calculated by the formula (length $\times$ width $\times$ width)/2, they were randomly divided into three groups. Pt-DHF and Pd-DHF at $10 \mathrm{mg} \mathrm{kg}{ }^{-1}$ body weight per day were administered intraperitoneally for a continuous period of 9 days starting from day 1. Each group consisted of five mice. Body weight of each animal was also recorded. On day 10 , mice were sacrificed and $H$ and $E$ staining of autopsy analysis including xenografted Hep3B tumour from all of the animals were investigated for any possible significant necrotic effects. Whole blood was also collected and plasma liver enzymes including alanine aminotransferase (ALT) and asparate aminotransferase (AST) were measured by the Vet biochemistry assay kit for the IDEXX laboratories machine to determine the hepatoma burden from the mice $[16,25]$.

\section{Acknowledgements}

This work is supported by the Innovation and Technology Commission to ABCT, HKPU, and the account codes: FRG1/14-15/ 021, FRG1/14-15/078 and 38-40-116 (C. H. Chui) as well as 03-16176 (X. Z. Bian). R. Gambari is supported by AIRC (IG-13575). We thank the National Natural Science Foundation of China (project number: 51373145), Hong Kong Research Grants Council (HKBU12304715), Areas of Excellence Scheme of HKSAR (AoE/P-03/ 08), the Science, Technology and Innovation Committee of Shenzhen Municipality (JCYJ20140419130507116 and JCYJ20140818163041143) and Hong Kong Baptist University (FRG1/ 14-15/084) for financial support. The work was also supported by Partner State Key Laboratory of Environmental and Biological Analysis (SKLP-14-15-P011) and Strategic Development Fund of HKBU. Q. Wang and C.-L. Ho thank the International Science and Technology Cooperation Program of Chengdu (2014-GH02-00014HZ) for financial support. Y. H. Lo gratefully acknowledges the financial support from the National Science Council of Taiwan (NSC 102-2113-M-845-001) and the project of the specific research fields in the University of Taipei, Taiwan.

\section{Appendix A. Supplementary data}

Supplementary data related to this article can be found at http:// dx.doi.org/10.1016/j.ejmech.2016.08.033.

\section{References}

[1] B. Rosenberg, L. VanCamp, T. Krigas, Inhibition of cell division in escherichia coli by electrolysis products from a platinum electrode, Nature 205 (1965) 698-699.

[2] B. Rosenberg, L. VanCamp, J.E. Trosko, V.H. Mansour, Platinum compounds: a new class of potent antitumour agents, Nature 222 (1969) 385-386.

[3] C.A. Rabik, M.E. Dolan, Molecular mechanisms of resistance and toxicity associated with platinating agents, Cancer Treat. Rev. 33 (2007) 9-23.

[4] Ž.D. Bugarčić, J. Bogojeski, B. Petrović, S. Hochreuther, R. van Eldik, Mechanistic studies on the reactions of platinum(II) complexes with nitrogen- and sulfur-donor biomolecules, Dalton Trans. 41 (2012) 12329-12345.

[5] J. Reedijk, Why does cisplatin reach guanine-N7 with competing S-donor ligands available in the cell? Chem. Rev. 99 (1999) 2499-2510.

[6] M.A. Fuertes, C. Alonso, J.M. Perez, Biochemical modulation of cisplatin mechanisms of action: enhancement of antitumor activity and circumvention of drug resistance, Chem. Rev. 103 (2003) 645-662.

[7] A.R. Kapdi, I.J.S. Fairlamb, Anti-cancer palladium complexes: a focus on PdX2L2, palladacycles and related complexes, Chem. Soc. Rev. 43 (2014) $4751-4777$

[8] M.R. Maurya, B. Uprety, F. Avecilla, S. Tariq, A. Azam, Palladium(II) complexes of OS donor $\mathrm{N}$-(di(butyl/phenyl)carbamothioyl)benzamide and their antiamoebic activity, Eur. J. Med. Chem. 98 (2015) 54-60.

[9] N. Bandyopadhyay, M. Zhu, L. Lu, D. Mitra, M. Das, P. Das, A. Samanta J.P. Naskar, Synthesis, structure, spectral characterization, electrochemistry and evaluation of antibacterial potentiality of a novel oxime-based palladium(II) compound, Eur. J. Med. Chem. 89 (2015) 59-66.

[10] S. Utku, A.B. Ozçelik, F. Gümüș, S. Yılmaz, T. Arsoy, L. Açık, A. Celebi Keskin, Synthesis, in-vitro cytotoxic activity and DNA interactions of new dicarboxylatoplatinum(II) complexes with 2-hydroxymethylbenzimidazole as carrier ligands, J. Pharm. Pharmacol. 66 (2014) 1593-1605.

[11] D. Kovala-Demertzi, A. Galani, J.R. Miller, C.S. Frampton, M.A. Demertzis, Synthesis, structure, spectroscopic studies and cytotoxic effect of novel palladium(II) complexes with 2-formylpyridine-4-Nethyl-thiosemicarbazone: potential antitumour agents, Polyhedron 52 (2013) 1096-1102.

[12] W.M. Motswainyana, M.O. Onani, A.M. Madiehe, M. Saibu, N. Thovhogi, R.A. Lalancette, Imino-phosphine palladium(II) and platinum(II) complexes: synthesis, molecular structures and evaluation as antitumor agents, J. Inorg. Biochem. 129 (2013) 112-118.

[13] W.M. Motswainyana, M.O. Onani, A.M. Madiehe, M. Saibu, Antitumor activity of phenylene bridged binuclear bis(imino-quinolyl)palladium(II) and platinum(II) complexes, Bioorg. Med. Chem. Lett. 24 (2014) 1692-1694.

[14] W.X.C. Oliveira, M.M. da Costa, A.P.S. Fontes, C.B. Pinheiro, F.C.S. de Paula, E.H.L. Jaimes, E.F. Pedroso, P.P. de Souza, E.C. Pereira-Maia, C.L.M. Pereira, Palladium(II) and platinum(II) oxamate complexes as potential anticancer agents: structural characterization and cytotoxic activity, Polyhedron 76 (2014) 16-21.

[15] C. Barbara, P. Orlandi, G. Bocci, A. Fioravanti, A. Di Paolo, G. Natale, M. Del Tacca, R. Danesi, In vitro and in vivo antitumour effects of novel, orally active 
bile acid-conjugated platinum complexes on rat hepatoma, Eur. J. Pharmacol 549 (2006) 27-34.

[16] Q. Wang, C.W.M. Yuen, C.L. Ho, K.H. Lam, R. Gambari, R.S.M. Wong G.Y.M. Cheng, S.W. Tong, K.W. Chan, F.Y. Lau, F. Cheung, C.H. Chui, W.Y. Wong Synthesis of 9,9-dialkyl-4,5-diazafluorene derivatives and their structure-activity relationships toward human carcinoma cell lines, ChemMedChem 5 (2010) 559-566.

[17] J.A. Weinstein, M.T. Tierney, E.S. Davies, K. Base, A.A. Robeiro, M.W. Grinstaff Probing the electronic structure of platinum(II) Chromophores: crysta structures, NMR structures, and photophysical properties of six new bis- and di- phenolate/thiolate Pt(II)Diimine chromophores, Inorg. Chem. 45 (2006) 4544-4555.

[18] G.L. Lu, C.L. Ho, Q. Wang, W.Y. Wong, C.H. Chui, R.S.M. Wong, R. Gambari, F.Y. Lau, M.C.W. Yuen, C.S.W. Tong, A.K.W. Chan, J.C.O. Tang, K.P. Ho, G.Y.M. Cheng, Synthesis and characterization of some metal complexes of 4,5diazafluoren-9-one and their biological effects on human carcinoma cells, Aust. J. Chem. 61 (2008) 975-980.

[19] U. Jungwirth, C.R. Kowol, B.K. Keppler, C.G. Hartinger, W. Berger, P. Heffeter Anticancer activity of metal complexes: involvement of redox processes, Antioxid. Redox Signal 15 (2011) 1085-1127.
[20] SAINT, Reference Manual, Siemens Energy and Automation, Madison, WI, 1994-1996.

[21] G.M. Sheldrick, SADABS, Empirical Absorption Correction Program, University of Göttingen, 1997.

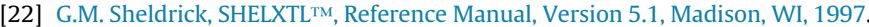

[23] P.L. Lam, G.L. Lu, K.H. Choi, Z Lin, S.H.L. Kok, K.K.H. Lee, K.H. Lam, H. Li, R. Gambari, Z.X. Bian, W.Y. Wong, C.H. Chui, Antimicrobial and toxicological evaluations of the binuclear mercury(II) bis(alkynyl) complexes containing oligothiophenes and bithiazoles, RSC Adv. 6 (2016) 16736-16744.

[24] P.L. Lam, G.L. Lu, K.M. Hon, K.W. Lee, C.L. Ho, X. Wang, J.C.O. Tang, K.H. Lam, R.S.M. Wong, S.H.L. Kok, Z.X. Bian, H. Li, K.K.H. Lee, R. Gambari, C.H. Chui, W.Y. Wong, Development of ruthenium(ii) complexes as topical antibiotics against methicillin resistant Staphylococcus aureus, Dalton Trans. 43 (2014) 3949-3957.

[25] K.H. Lam, K.K.H. Lee, R. Gambari, S.H.L. Kok, T.W. Kok, A.S.C. Chan, Z.X. Bian, W.Y. Wong, R.S.M. Wong, F.Y. Lau, S.W. Tong, K.W. Chan, C.H. Cheng, C.H. Chui, J.C.O. Tang, Anti-tumour and pharmacokinetics study of 2-Formyl8-hydroxy-quinolinium chloride as Galipea longiflora alkaloid analogue, Phytomedicine 21 (2014) 877-882. 